\title{
Employment, Capital and Seasonality in Selected Mediterranean Countries*
}

\author{
Alka Obadic * \\ Lorena Pehar ${ }^{* * * *}$
}

\begin{abstract}
The paper examines the influence of tourism industry on GDP, employment and capital investments in selected Mediterranean countries (Croatia, France, Greece, Italy and Spain). It points out important contribution which tourism has on economic activity and capital investment of selected economies and labour market. The analysis highlights the importance of tourism strength in generating employment. It synthesizes data on tourism employment and employment according to educational level. The results show that the quality of human capital is increasing but at the same time indicating gender discrimination in tourism labour market. Despite women being the majority of higher education degree holders in tourism, men hold upper-management and decision-making positions more often than women do. Lastly the paper indicates strong contribution of tourism sector in GDP and total employment in selected countries showing strong problem of seasonality.
\end{abstract}

Keywords: tourism impact; tourism contribution; educational level; seasonal employment

JEL Classification: J40, J70, Z30

\section{Introduction}

In recent decades the service sector is seen as increasingly important for most of the economies in many ways. At the same time, tourism is recognized as a many-sided and rapidly expanding economic activity relying predominantly on the service sector and labour force. The main objective of this paper is to assess the impact of tourism industry on main macroeconomic variables (GDP, employment and capital

\footnotetext{
* This work has been fully supported by Croatian Science Foundation under the project 7031.

** Alka Obadić is at University of Zagreb, Faculty of Economics and Business, Zagreb, Croatia.

*** Lorena Pehar is graduate student at at University of Zagreb, Faculty of Economics and Business, Zagreb, Croatia.
} 
investments) in selected Mediterranean countries. Tourism jobs are among the most attractive available to both men and women - both in terms of salary and job satisfaction (Obadić, Marić, 2009). The main limitation of tourism employment is the fact that in the majority of European countries it has a seasonal character. Therefore, this research highlight the problem of seasonality and seasonal employment concentrated in the summer months in selected Mediterranean countries (Croatia, France, Greece, Italy and Spain). The intention of this paper is to point out important contribution which tourism has on economic activity and capital investment of selected economies and labour market. With the analysis of available secondary data analytical part of the paper explores characteristics of tourists by sociodemographic characteristics (employment according to educational attainment level, age groups and gender). Our data confirms constantly increasing educational attainment in selected countries. Tourism is a female-dominated sector in most countries. It is characterized by a predominance of low salaries, as well as unsociable working hours, such as working during holidays, nights, and weekends, which complicates work-family balance (Costa, et al., 2014b, 296).

\section{Literature Review}

In the last sixty years, tourism is experiencing continuous expansion and diversification. It is one of the biggest and fastest growing sectors in the global economy and has significant environmental, cultural, social and economic effects. Number of foreign tourist arrivals globally rose from 25 million in 1950 to 278 million in 1980, with 674 million in 2000 to almost 1.2 billion arrivals in 2015 (UNWTO, 2016, p. 2). Leading tourist destinations in 2015 according to the amount of the revenue generated from international tourism and the number of foreign tourist arrivals were France, the United States, Spain and China with Europe as the world's most visited and fastest growing region in absolute terms (UNWTO, 2016, p. 3). With 61.1 million foreign tourists in 2014, Croatia achieved a very good eighth place on the scale of the EU countries (Rašić Bakarić, 2016, 17).

Tourism plays an important role in the EU because of its economic and employment potential, as well as its social and environmental implications. In macroeconomic terms, the impact of tourism industry on GDP, employment and capital investments is the most important. Tourism strength in creation of new jobs is especially interested in the post-crisis period. Formal education plays an undeniably critical role in the development of a skilled and competent workforce, because the tourism industry is comprised of many different types and levels of work at a variety of organizational levels, the development of a qualified workforce capable of satisfying all human resource needs in the tourism industry is an extremely challenging task for many countries (Yeşiltaş, Öztürk, Hemmington, 2010, p. 63). 
The analysis presented by Costa and others suggests that pursuing postgraduate degrees in the tourism field leads to better outcomes in the labour market, as tourism postgraduates are less likely to be unemployed and earn higher salaries. Gender inequalities also seem to be less pronounced among postgraduates (Costa, et al., 2014b, 312). However, it is observed that despite women being the majority of higher education degree holders in tourism, men hold upper-management and decision-making positions more often than women do, besides earning better salaries. The proportion of men in leadership positions almost doubles the one of women (Costa, et al., 2014a, 194-203; Cave, Kilic, 2010). Women are concentrated in the lower levels in occupations with few opportunities for upward mobility while men dominate the key managerial positions (Parrett, 2004, 10). In such a way, tourism industry segregates women into areas of employment which commercialize their perceived domestic skills and "feminine" characteristics (Obadić, Marić, 2009).

Seasonality has long been recognized as one of the most distinctive features of tourism, and after the movement of people on a temporary basis, may be the most typical characteristic of tourism on a global basis. After the review of scientific literature (Butler, 1994; Butler, 2001; Koenig-Lewis, Bischoff, 2010; Baum, Lundtorp, 2011; Cisneros-Martínez, Fernández-Morales, 2015; Coshall et al., 2015) in the field of tourism it can be concluded that the phenomenon of seasonality, a subject that attracts attention of scientists and experts in the field of tourism for many years, is recognized as one of the key features of tourism activities. From all available definitions of seasonality, in the scientific literature the most accepted and cited one is Butler's, which defined seasonality as a temporal imbalance in the phenomenon of tourism, which may be expressed in terms of dimensions of such elements as numbers of visitors, expenditure of visitors, traffic on highways and other forms of transportation, employment and admissions to attractions (Butler, 1994).

The most frequently expressed opinion appears to be that the seasonal nature of tourism presents problems for employers, making it difficult to recruit full-time staff and to retain them (Krakover, 2000). Mourdoukoutas (1988) argues that a considerable number of employees choose seasonal tourism employment because it pays better than alternative work that is available, and also because it allows those who wish to pursue other activities during the off-season to do so. Undoubtedly, however, the overwhelming impression from the literature is that seasonality in tourism is a problem (Baum, Lundtorp, 2011).

\section{Data Limitations and Measuring}

Considering data covering, this paper draws on an extensive range of secondary sources, both statistical and analytical. The data of selected Mediterranean countries (Croatia, France, Greece, Italy and Spain) have been gathered according to the 
Eurostat Database, UN World Tourism Organisation and World Travel and Tourism Council's (WTTC) publications in order to provide adequate analysis of secondary data. Variables taken in consideration are the number of international tourist arrivals, capital investment in tourism sector, direct contribution of tourism in GDP, employment share in tourism, employed persons in tourism by educational attainment level and employment seasonality. Selected countries are compared with EU28 average where possible.

Travel and Tourism is an important economic activity in most countries around the world with large "multiplier effects". Total coverage of economic impact of tourism is very complex and difficult, so it is its measuring (Smeral, 2015). As well as its direct economic impact, the sector has significant indirect and induced impacts. The UN Statistics quantifies only direct contribution of Travel and Tourism. WTTC recognises that Travel and Tourism's total contribution is wider, and aims to capture its indirect and induced impacts through its annual research (Oxford Economics, 2016, 3).

Mediterranean countries are chosen because of their popularity as tourist destinations, wealth of history, culture, tradition and spectacular nature and scenery. France, Italy and Spain represent big developed countries with diverse tourist offer which is constantly improving. In 2014, Spain was the most common tourism destination in the EU for non-residents with 260 million nights spent in tourist accommodation establishments, or $21.5 \%$ of the EU-28 total (Eurostat, 2015). Across the EU, the top three most popular tourism destinations in 2014 for non-residents were Spain $(259,6$ million nights), Italy (187 million nights) and France (131 million nights). Greece and Croatia followed immediately behind if we consider just Mediterranean region, but in EU28 they are in top ten (see table 1).

Table 1: Top 10 tourism destinations in EU28 - nights spent at tourist accommodation establishments, 2014 (million nights spent in the country by non-residents)

\begin{tabular}{|c|c|c|c|}
\hline Rank & Country & Nights in country & Share (\%) \\
\hline & EU28 & $1.207,30$ & 100,0 \\
\hline & Top 10 & $1.041,60$ & 86,3 \\
\hline 1 & Spain & 259,6 & 21,5 \\
\hline 2 & Italy & 186,9 & 15,5 \\
\hline 3 & France & 130,9 & 10,8 \\
\hline 4 & UK & 105,5 & 8,7 \\
\hline 5 & Austria & 78,1 & 6,5 \\
\hline 6 & Germany & 74,8 & 6,2 \\
\hline 7 & Greece & 74,7 & 6,2 \\
\hline 8 & Croatia & 61,1 & 5,1 \\
\hline 9 & Portugal & 35,6 & 3,0 \\
\hline 10 & Netherlands & 34,4 & 2,9 \\
\hline
\end{tabular}

Source: Eurostat (2015). 
France is the fourth largest tourism earner with US\$46 billion reported in 2015, but the world's top destination in terms of arrivals with 84 million tourists in 2015 (UNWTO, 2016, p. 6). Spain's tourism industry is markedly seasonal throughout the year, in turn resulting in the considerable underutilisation of tourism infrastructures. Italy offers a similar type of tourism and is even more seasonal. Croatia served as an example of small developing country in which tourism has an important role. The number of nights spent (by residents and non-residents) can be put into perspective by making a comparison with the size of each country in population terms, providing an indicator of tourism intensity. According to tourism intensity ${ }^{1}$ in 2014, Croatia (with 15.6 nights spent), as well as the alpine and city destinations of Austria were the most popular tourist destinations in the EU-28 (Eurostat, 2015). Greece ranks among the EU countries which have been hit really hard by the international economic crisis (real GDP decrease in 2001 was 9.1\%), (Eurostat, 2016). The crisis also had an impact on tourism in Greece, which is particularly important since its economy is based on service sector. Namely, tourism direct and indirect effects are more than $17 \%$ of GDP and, therefore, tourism is the backbone of the Greek economy.

\section{Statistical Analysis}

Economic impact of tourism is mainly measured in terms of its effect on gross domestic product (GDP), employment, investment and development and balance of payment. This paper concentrates on the first three variables. In this statistical part of the analysis, paper is composed of three major sections.

\section{The Importance of Tourism Industry in the Economies of Selected Countries}

Tourism is one of the world's leading industries and is a growth industry globally. Therefore, it has a strong impact on a wide variety of economies, in both the developing and the developed world. One of the principal indicators for assessing the tourist traffic is the number of tourist arrivals (see table 1). In macro-economic terms, expenditure by international visitors counts as exports for the destination country and as imports for the country of residence of the visitor (UNWTO, 2016, 5). International arrivals in Southern and Mediterranean Europe grew by 5\% in 2015 (UNWTO, 2016, 7). 
Table 2: Number of international tourist arrivals in selected countries, 2000-2015, in millions

\begin{tabular}{|l|r|r|r|r|r|r|r|r|r|r|r|r|}
\hline & $\mathbf{2 0 0 0}$ & $\mathbf{2 0 0 5}$ & $\mathbf{2 0 0 6}$ & $\mathbf{2 0 0 7}$ & $\mathbf{2 0 0 8}$ & $\mathbf{2 0 0 9}$ & $\mathbf{2 0 1 0}$ & $\mathbf{2 0 1 1}$ & $\mathbf{2 0 1 2}$ & $\mathbf{2 0 1 3}$ & $\mathbf{2 0 1 4}$ & $\mathbf{2 0 1 5}$ \\
\hline Croatia & 5,9 & 8,0 & 8,2 & 8,6 & 8,7 & 8,3 & 7,9 & 8,5 & 11,5 & 12,2 & 12,9 & 14,2 \\
\hline France & 114,1 & 125,3 & 124,4 & 127,0 & 126,3 & 124,0 & 125,9 & 148,8 & 148,9 & 153,7 & 153,0 & 157,6 \\
\hline Greece & 14,0 & 13,4 & 14,0 & 16,0 & 16,0 & 20,9 & 20,6 & 21,1 & 18,2 & 20,1 & 21,8 & 23,1 \\
\hline Italy & 80,0 & 88,3 & 93,0 & 96,2 & 95,5 & 95,5 & 98,8 & 103,7 & 103,7 & 103,9 & 106,6 & 113,4 \\
\hline Spain & 74,4 & 87,6 & 99,9 & 101,8 & 100,1 & 93,7 & 98,8 & 103,1 & 100,4 & 101,7 & 107,5 & 114,3 \\
\hline
\end{tabular}

Source: Eurostat Database (2016).

Table 1 shows the overall number of tourist arrivals in five selected countries between 2000 and 2015. Data show that there has been an upward trend in arrivals in all the selected countries over the last 15 years which resulted in a peak in 2015. As is observed from the given table, the highest number of arrivals in 2015 had France (157.6 millions) and Spain follows with 114.3 million respectively. Greece and Croatia have significantly lower number of arrivals but their smaller size should also be taken in consideration. When comparing absolute differences in arrivals from 2000 to 2015, France has the biggest improvement. Even though, France has the highest absolute difference in arrivals (43.5 million), and Croatia the lowest ( 8.3 million), the highest relative difference can be noticed. To be exact, the number of arrivals in Croatia has improved $140.68 \%$ between 2000 and 2015. In all observed countries, arrivals have tended to increase over time, so that they are 38-140\% higher in 2015 than 15 years ago. The economic crisis downsized the number of arrivals in France, Spain and Croatia but pre-crisis levels were reached again in 2011. The number of arrivals increased during the whole crisis period in Italy.

The number of tourist arrivals increased further in 2015 in the World as a whole. International tourist arrivals in Europe increased 4.7\% in 2015 compared to the same period last year, consolidating the solid increase recorded over the past six years, since the 2009 financial crisis. Southern and Mediterranean Europe saw a 4.8\% increase in arrivals in 2015, as the economic recovery advances and lower oil prices help keep travel costs down. Strong appetite for leisure travel and the good summer weather boosted inbound tourism in the sub region. Spain, the world's third largest tourism destination, recorded 5\% more international arrivals, partly to the strong demand from the UK. Italy, reported a $4.4 \%$ increase in arrivals and France only $0.9 \%$. The cause can be found in recent terrorist attacks in Paris which no longer makes France a safe destination in the eyes of the tourists and travellers. Strong increase was recorded in Greece (7.1\%) and Croatia (9.1\%) (UNWTO, 2016, 8).

Due to the role of tourism in these countries' economies, it is crucial to emphasize capital investment in tourism industry. Those investments include capital investment spending by all industries directly involved in travel and tourism. This also constitutes investment spending by other industries on specific tourism assets such as new 
visitor accommodation and passenger transport equipment, as well as restaurants and leisure facilities for specific tourism use (WTTC, 2016).

Figure 1: Capital investment in tourism sector in selected countries, 2000-2016 (in billion dollars, real prices)

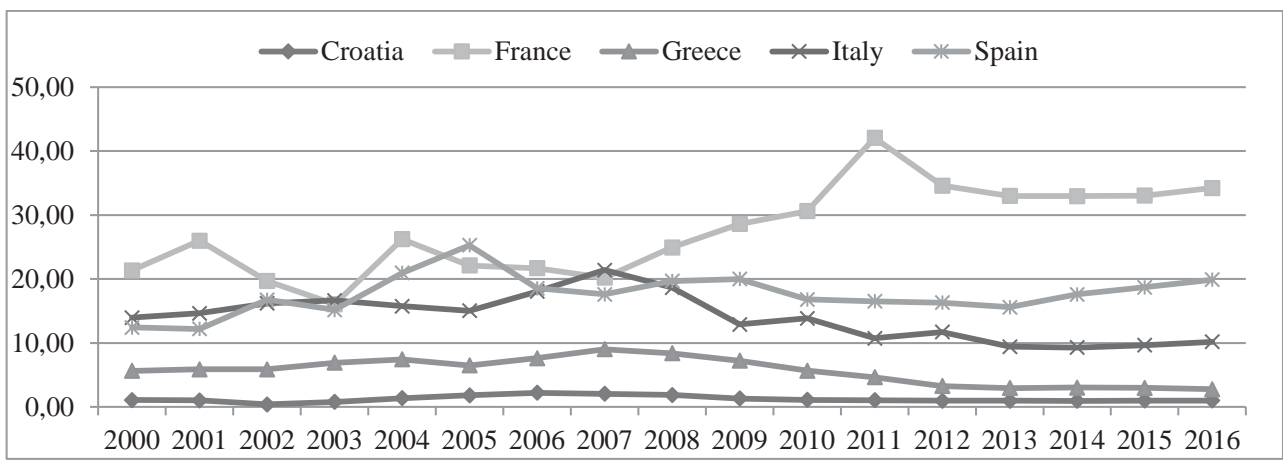

Source: WTTC (2016).

Figure 1 shows that capital investment in tourism sector is the highest in France (ranging from 21.3 to 34.2 billion dollars) and lowest in Croatia (from 1.08 to 1.00) in the given period. Considering the number of arrivals (table 2), it can be noticed that relation between number of arrivals and capital investment exists. Countries with the highest number of overall arrivals (France and Spain) have the highest capital investment in tourism sector (France and Spain). In order to test the measure of strength of the association between these two variables, the correlation between these two sets of data is measured by Pearson Correlation coefficient ( $r$ ) (see table 1).

Table 3: Correlations between number of arrivals and capital investment

\begin{tabular}{|l|c|c|c|c|c|}
\hline & Croatia & Greece & France & Italy & Spain \\
\hline Pearson Correlation coefficient $(r)$ & $-0,11$ & $-0,59$ & 0,81 & $-0,57$ & 0,28 \\
\hline
\end{tabular}

Note: Correlation is significant at the 0.05 level (2-tailed).

The value of Pearson coefficient for Croatia indicates very small correlation between these two variables. Unfortunately, capital investments in tourism in Croatia had a continuous downward trend in last ten years and from 2011 we are witnessing tremendous increase in international tourist arrivals with 14.2 million records in 2015. The correlation values for Greece and Italy are relatively high and negative indicating negative correlation between number of arrivals and capital investment in observed period showing that as one variable increases, other decreases or stagnates. That happened in Greece and Italy in 2008 with beginning of economic crisis. As 
capital investments started to decrease in 2008 in both countries, tourist arrivals increased almost for 5 million in Greece and stagnated for two years in Italy. After 2010 number of tourist arrivals recovered in both countries, but capital investments continued to fall. France and Spain demonstrate positive correlation between two variables, but the relation is much stronger in France $(0.81)$ because of the huge capital investment increase from 2008. Namely, France almost did not feel capital investments vulnerability in tourism sector during the crisis.

The significance of the tourism sector in the economy can also be noticed by analysing its share in GDP. Considering the level of investments in tourism, it is presumable that tourism has high direct contribution to the countries' GDP²(see Table 3).

Table 4: Direct contribution of tourism in GDP of the selected countries, 2005-2016, $\%$

\begin{tabular}{|l|c|c|c|c|c|c|c|c|c|c|c|c|}
\hline & $\mathbf{2 0 0 5}$ & $\mathbf{2 0 0 6}$ & $\mathbf{2 0 0 7}$ & $\mathbf{2 0 0 8}$ & $\mathbf{2 0 0 9}$ & $\mathbf{2 0 1 0}$ & $\mathbf{2 0 1 1}$ & $\mathbf{2 0 1 2}$ & $\mathbf{2 0 1 3}$ & $\mathbf{2 0 1 4}$ & $\mathbf{2 0 1 5}$ & $\mathbf{2 0 1 6}$ \\
\hline EU28 & $\mathbf{3 , 8}$ & $\mathbf{3 , 8}$ & $\mathbf{3 , 7}$ & $\mathbf{3 , 6}$ & $\mathbf{3 , 6}$ & $\mathbf{3 , 5}$ & $\mathbf{3 , 6}$ & $\mathbf{3 , 6}$ & $\mathbf{3 , 7}$ & $\mathbf{3 , 7}$ & $\mathbf{3 , 7}$ & $\mathbf{3 , 8}$ \\
\hline Croatia & 9,7 & 9,6 & 9,6 & 10,1 & 9,2 & 8,4 & 9,1 & 8,8 & 9,5 & 9,9 & 10,1 & 10,2 \\
\hline France & 3,7 & 3,6 & 3,7 & 3,7 & 3,6 & 3,5 & 3,7 & 3,7 & 3,7 & 3,7 & 3,7 & 3,7 \\
\hline Greece & 5,8 & 5,6 & 5,4 & 5,4 & 5,6 & 5,4 & 5,9 & 6,0 & 7,0 & 7,5 & 7,6 & 7,7 \\
\hline Italy & 4,3 & 4,3 & 4,2 & 4,0 & 3,8 & 3,8 & 3,9 & 3,9 & 4,0 & 4,1 & 4,2 & 4,2 \\
\hline Spain & 5,6 & 5,6 & 5,5 & 5,5 & 5,1 & 5,2 & 5,4 & 5,5 & 5,6 & 5,7 & 5,8 & 5,7 \\
\hline
\end{tabular}

Source: WTTC (2016).

Compared to the EU average, the share of direct tourism influence on GDP of selected countries is almost three times higher in Croatia and twice as high in Greece. The data points out Croatia's heavy reliance on tourism, as direct contribution of tourism industry makes $10.2 \%$ of Croatia's GDP in 2016. The lowest dependence on tourism is found in France since it contributes to its GDP with 3.7\%. In Spain and Greece, total contribution of tourism was $5.7 \%$ and $7.7 \%$ in 2016, while in Italy this percentage was $4.2 \%$. In all selected countries, this indicator mostly remained stable in the past eleven years regardless of the crisis. From 2005, it increased in Croatia (by $0.5 \%$ points) and Greece (by $1.9 \%$ points) but declined in and Italy (by $0.1 \%$ points). In France and Spain it stayed the same and hasn't changed a lot trough the period of eleven years. In other words, dependence of Croatian and Greek economic activity on tourism industry is slightly rising while it is reducing in Italy. It can be concluded that, in spite of a considerable rise in the total number of arrivals over the last decade, the tourism in France, Spain and Italy did not attain a rise in its contribution in GDP.

Increased tourist demand is reflected in the increasing demand for labour force and increasing number of seasonal jobs in tourism. Therefore, tourism has a significant effect on tourist countries labour market by increasing employment during the season. Tourism employment can be categorized at two separate levels depending 
on their involvement in or contribution to tourism supply-side. Front offices in hotels, restaurants, travel agencies, tourism information offices, aircrafts, cruise lines, resorts or shopping outlets provide direct employment because their employees are in contact with tourists and cater for tourist demand. Tourism also supports indirect employment in activities like restaurant suppliers, construction companies that build and maintain tourist facilities, as well as necessary infrastructure, aircraft manufacturers, various handicrafts producers, marketing agencies, accounting services, which are more or less dependent on the companies providing direct employment for their revenues (UNWTO, 2016). Figure 2 shows employment share in tourism (includes activities of accommodation and food service) as a share of total employment in selected countries from 2008 to 2015.

Figure 2: Employment share of tourism in total employment in selected countries, $(2008-2015), \%$

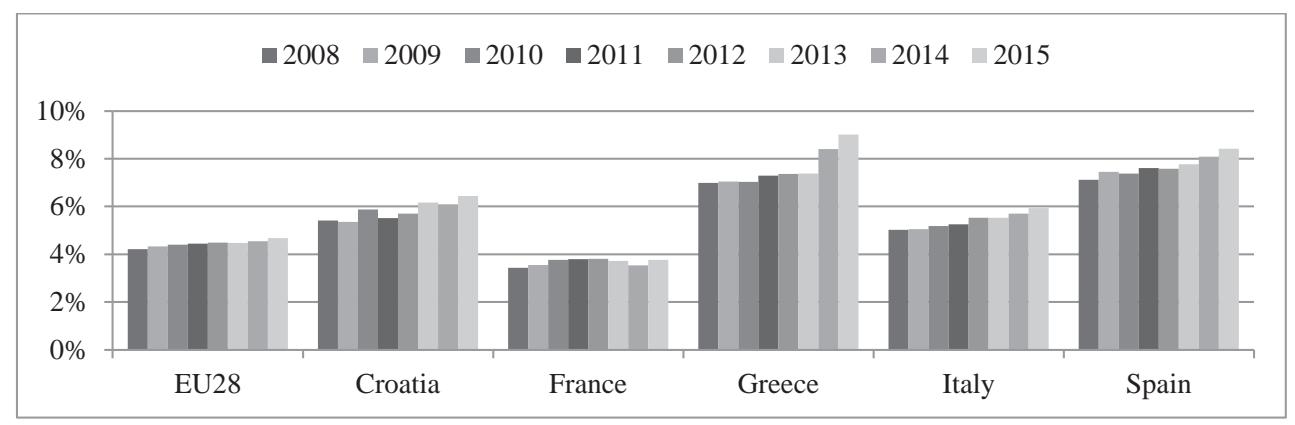

Source: Eurostat Database (2016).

The EU28 employment share in tourism increases through the years from $4.22 \%$ in 2008 to $4.68 \%$ in 2015. The employment share of tourism in total employment shows that Croatia (6.44\% in 2015) has almost 2 times higher share than the EU average. The situation is similar in Greece, but employment share of tourism in total employment is higher than in Croatia. In all observed countries, the share of employed persons in tourism fluctuated in selected years. Until 2011 employment share of tourism was mostly decreasing and in 2015 there was a noticeable increase as a result of the recovery of tourism demand. Considering Croatia, employment share in tourism fluctuated in whole observed period and in 2015 reached $6.44 \%$ of total employment, which represents the highest employment share in Croatia in the observed period. Greece had the highest employment share in all selected countries of Mediterranean region in 2015 (9.01\%), while France had the lowest (3.77\%). 


\section{The Impact of Educational Attainment on Employment in Tourism Industry}

Previous part confirmed a significant role of tourism in creation of new jobs in analysed countries. Analysis of educational level is explored according to International Standard of Classification of Education (ISCED) ${ }^{3}$. Regarding the classification of economic activities, this data refers to accommodation and food service activities. Figure 3 shows number of employed persons in tourism according by educational level for each country separately.

Figure 3: Employed persons in tourism industry by educational attainment level (02, 3-4, 5-8) in the selected countries, 2008-2015, in thousand

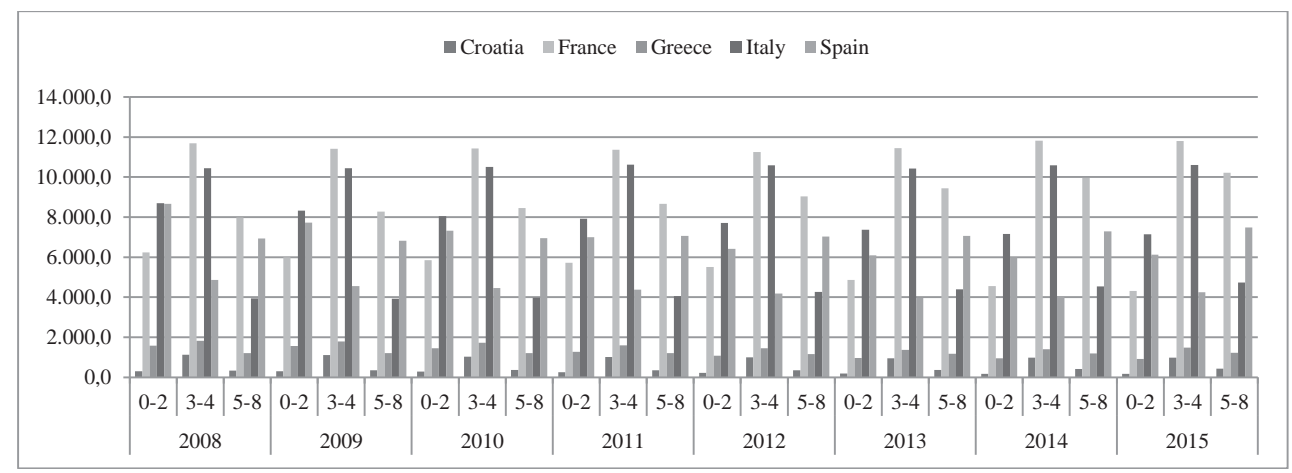

Source: Eurostat Database (2016).

Most people employed in tourism sector in Greece, in the period between 2008 and 2015, had upper secondary and post-secondary non-tertiary education (levels 3 and 4) but this number is constantly decreasing. In 2008, there were $1,818,200$ people employed in tourism and by the year 2015 it had fallen to $1,475,800$. The number of employed persons with primary and lower secondary education (levels $0-2$ ) is also declining. In the observed period, the number of tertiary educated employees is fluctuating, ranging from 1,161,900 (2012) to 1,213,300 (2010). At the end of the observed period, there were 1,220,500 tertiary educated employees in tourism sector in Greece. In Spain, most of the workers in tourism have primary and lower secondary education (levels 0-2) and tertiary education (levels 5-8). From 2008 to 2010, workers in tourism were mainly primary educated. In 2011, the number of primarily and tertiary educated was almost the same but in favour of higher level of education. From 2011 to 2015, this number is constantly increasing peaking at 7,480,600 at the end of the observed period. In Croatia, the observation is similar to the one in Greece. Most people employed in tourism sector in Croatia had upper secondary and post-secondary non-tertiary education (levels 3 and 4 ) and this number is decreasing in the given period. Furthermore, the number of employed persons in tourism with levels $0-2$ is 
also declining. On the contrary, number of employed persons that have the highest level of educational attainment is continually improving. In Italy, most of the workers in tourism have upper secondary and post-secondary non-tertiary education (levels 3 and 4) and this number remains mostly stable throughout the years, ranging between 10,430,700 (2013) and 10,614,900 (2011). In France, most people employed in tourism sector had upper secondary and post-secondary non-tertiary education (levels 3 and 4) and this number is fluctuating in the given period ranging from 11,248,800 (2012) to $11,806,200$ (2015). Number of people with primary and lower secondary education (levels 0-2) are constantly decreasing in the given period, while the number of people with tertiary education level (levels 5-8) are constantly increasing which resulted in a peak in 2015 (10,223,000 people).

Analysis of average number of employed workers by educational attainment in selected countries from the beginning of economic crisis shows that the number of employed workers in tourism industry with upper secondary and post-secondary non-tertiary education (levels 3 and 4) have slightly decreased while those with primary and lower secondary education (levels 0-2) decreased significantly. Moreover, the number of employed persons with highest educational level (levels 5-8) is constantly improving. The analysis points out the expanding role of educational attainment in tourism and highlights the advancement of the highest educational level.

\section{Seasonality and Seasonal Employment}

Seasonality has been viewed as a major problem for the tourism industry and has been held responsible for creating or exacerbating a number of difficulties faced by the industry, including problems in gaining access to capital, in obtaining and holding full-time staff, for low returns on investment, etc. Conversely, it has also been blamed for the under-utilization of these resources and facilities, often preventing tourism being accepted as a viable economic activity in many areas. It is therefore not surprising, that considerable efforts have been made both by public and private sectors to attempt to reduce seasonality in destination areas through a variety of approaches. The effects of seasonality on employment tourism destination areas present several viewpoints.

The presence of seasonality can be confirmed also in the case of five analysed countries. Figure 4 shows quarterly data for average employed persons in accommodation and food service activities from 2008-2016 in order to clearly indicate the fluctuation in number of employed persons depending on the time of the year. Due to the geographical position of Croatia, France, Greece, Italy and Spain at the Mediterranean Sea, they have mainly developed 3S type of tourism (sun, sand and sea) which peaks in the third quarter. 
Figure 4: Average employed persons in tourism (Accommodation and food service activities) in selected countries - quarterly data, 2008-2016, in thousands

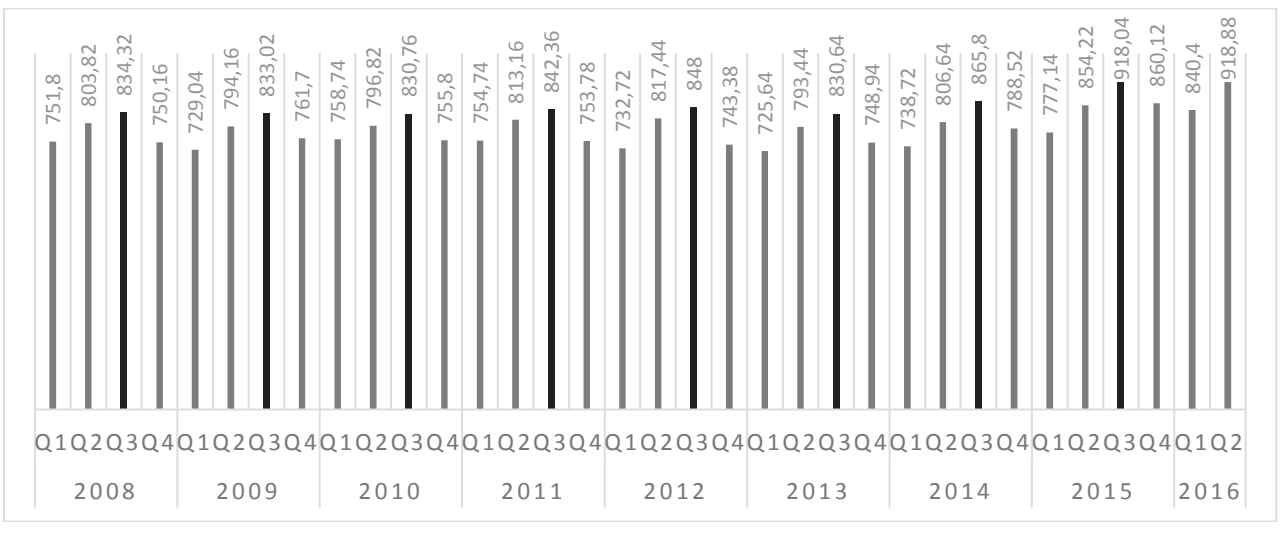

Source: Eurostat Database (2016).

Figure 4 emphasizes that the highest average employment is in the third quarter (black column) in each consecutive year of the observed period. The number of employed persons in tourism is the lowest in first quarter (January, February, March) and it starts increasing in second quarter when the season starts. After its peak in the third quarter, it sharply decreases in the fourth quarter to the level of employment similar to the one in first three months of the year.

Another way to evaluate seasonality is to look at the difference between the peak and the bottom months. On average for the EU-28, this ratio was 4.0. This means that occupancy (in nights spent) of accommodation establishments was 4 times higher in the peak month (August) than in the trough month (January). Using this measure, the country with the highest seasonality was Croatia, where more than 23.6 million nights spent were recorded in August, 66.9 times more than the 353000 nights spent in January. $32.77 \%$ of all nights spent in Croatia were recorded in August - the highest monthly share in the EU in 2015. The high degree of seasonality in Croatian tourism industries can be partially explained by strong focus on coastal tourism (Demunter, Dimitrakopoulou, 2014). Since 2001, the degree of seasonality of Croatian tourism was in a slight decline until the beginning of the Great Recession, when it starts to rise again. The lowest degree of seasonality was recorded in the case of domestic tourists. Given the type of accommodation facilities and different tourism regions of Croatia, the lowest degree of seasonality was recorded in hotel accommodation, and the Dubrovnik area (Kožić, et al., 2013, p. 181).

The second highest ratio was found in Greece, where the number of nights spent in the peak month (August) exceeded that of the slowest month (January) by a factor of 16.5 (Eurostat, 2015). The analysis can be extended to the share of tourism nights 
spent in tourist accommodation establishments during the busiest and the slowest months in 2015 (two peak and two slowest months), (table 4).

Table 5: Share of tourism nights spent in tourist accommodation establishments in $2015(\%)$

\begin{tabular}{|l|c|c|c|c|}
\hline & \multicolumn{4}{|c|}{ Share of the nights spent in the two } \\
\hline & \multicolumn{3}{|c|}{ Busiest months } & \multicolumn{2}{c|}{ Slowest months } \\
\hline & AUG & JUL & JAN & FEB/NOV \\
\hline EU28 & 17,41 & 15,68 & 4,37 & 4,50 \\
\hline Croatia & 32,77 & 28,15 & 0,49 & 0,50 \\
\hline France & 20,70 & 18,04 & 4,36 & 4,98 \\
\hline Greece & 23,76 & 20,81 & 1,19 & 1,23 \\
\hline Italy & 20,99 & 17,79 & 3,88 & 3,16 \\
\hline Spain & 16,20 & 13,84 & 4,35 & 4,65 \\
\hline
\end{tabular}

Source: Eurostat (2016).

At EU-28 level, the peak months of July and August 2015 accounted for $33.09 \%$ of nights spent in tourist accommodation. At the other end, the slowest months (November and January) represented less than $10 \%$ of the annual nights spent. The two peak months were most pronounced in Croatia (60.92\%) and Greece (44.57\%) while the two slowest months were least significant in selected countries. In the EU Member States, the peak months for the tourist accommodation sector were July and August, while the slowest months differ across the countries. The seasonal character of Croatian tourism cannot be explained merely through geographical conditions and established trend of holiday making in Europe. The crucial problem is the structure of accommodation capacities which is less favourable than with the Croatian competition (hotels and similar facilities account for only 13\%), (Čavlek, et al., 2010, p. 157).

\section{Conclusion}

The analysis verifies that the tourism sector has significant influence on the economic activity of selected Mediterranean countries (Croatia, France, Greece, Italy and Spain). Compared to the EU average, the share of direct tourism in GDP of selected countries is almost four times higher in Croatia and twice as high in Greece.

Tourism has a big impact on economic output. The data shows that Croatia significantly depends on tourism which contributes 10.2\% in Croatia's GDP in 2016. The lowest dependence on tourism is found in France and Italy since it contributes to its GDP with $3.7 \%$ and $4.2 \%$. In Greece and Spain, total contribution of tourism was $7.7 \%$ and $5.7 \%$ in 2016 . 
Tourism as a labour intensive economic activity generates a lot of directly and indirectly, jobs. Tourism employment share in total employment creates from 3.8\% in France to more than $9.0 \%$ in Greece.

The level of educational attainment in tourism is improving. The number of employed persons with highest educational level (levels 5-8) is constantly improving. The analysis points out the expanding role of educational attainment in tourism and highlights the advancement of the highest educational level.

Seasonality is highly expressed. Occupancy (in nights spent) of accommodation establishments was 4 times higher in the peak month (August) than in the trough month (January).

Moreover, given the good projections for global growth in tourism, tourism will become even more important in the coming years. Projections are that the recovery of tourism demand will especially effect new tourist arrivals in Mediterranean region, thus creating an even greater multiplier effect on economic activity and employment. We should take advantage of this to reduce the industry's extremely seasonal bias and thereby make better use of the available infrastructures.

\section{REFERENCES}

Baum, T., Lundtorp, S. (2011). Seasonality in tourism. Advances in Tourism Research Series. Pergamon, An Imprint of Elsevier Science, Kidlington, Oxford OX5 IGB, UK, 3-11. available at: http://samples.sainsburysebooks.co.uk/9781136367076_sample_481729.pdf (4.12.2016.)

Butler, R.W. (1994). Seasonality in tourism: issues and problems. In: AV.Seaton (Ed.) Tourism: the State of the Art (pp. 332-339). Chichester: John Wiley and Sons.

Butler, R.W. (2001). Seasonality in tourism: issues and implications. In: T.Baum and S. Lundtorp (Ed.), Seasonality in Tourism (pp. 5-21), Oxford: Pergamon.

Cave, P., Kilic, S. (2010). The Role of Women in Tourism Employment with special reference to Antaly, Turkey. Journal of Hospitality Marketing \& Management. 19(3), 280-292.

Cisneros-Martínez, J., Fernández-Morales, A. (2015). Cultural tourism as tourist segment for reducing seasonality in a coastal area: the case study of Andalusia. Current Issues in Tourism, 18(8), 765-784.

Coshall, J., Charlesworth, R., Page, S.J. (2015). Seasonality of Overseas Tourism Demand in Scotland: A Regional Analysis. Regional Studies, 49(10), 1603-1620.

Costa, C., Carvalho, I., Caçador, S., Breda, Z. (2014a). Future Higher Education in Tourism Studies and the Labor Markets: Gender Perspectives on Expectations and Experiences. In D. Prebežac, C. Schott, P.J. Sheldon (Eds.), The Tourism Education Futures Initiative (193-213). Routledge, New York, USA.

Costa, C., Caçador, S. Carvalho, I., Breda, Z., Costa, R. (2014b). The Influence of Gender and Education -Related Variables on Career Development: The Case of Portuguese and Brazilian Tourism Graduates. In D. Prebežac, C. Schott, P.J. Sheldon (Eds.), The Tourism Education Futures Initiative (295-316). Routledge, New York, USA.

Čavlek, N., Bartoluci, M, Kesar, O., Čižmar, S., Hendija, Z. (2010). Contribution to Croatia's new tourism policy framework. Acta touristica. 22(2), 131-252. 
Demunter, C. \& Dimitrakopoulou, K. (2014). Tourism statistics for Croatia. Statistics in focus 2/2014. ISSN: 2314-9647, Catalogue number: KS-SF-14-002-EN-N. Retrieved March 28, 2016 from http://ec.europa.eu/eurostat/statistics-explained/index.php/Tourism_statistics_for_Croatia

Eurostat (2015). Tourism statistics. Statistics Explained. Retrieved November 30, 2016 from http:// ec.europa.eu/eurostat/statistics-explained/index.php/Tourism_statistics

Eurostat (2016). Seasonality in the tourist accommodation sector. Statistics Explained. Retrieved November 20, 2016 from http://ec.europa.eu/eurostat/statistics-explained/index.php/Seasonality_in_the_tourist_accommodation_sector

Eurostat Database (2016). Retrieved November 21, 2016 from http://ec.europa.eu/eurostat/data/database

Koenig-Lewis, N., Bischoff, E.E. (2010). Developing Effective Strategies for Tackling Seasonality in the Tourism Industry. Tourism and Hospitality Planning \& Development. 7(4), 395-413.

Kožić, I., Krešić, D., Boranić-Živoder, S. (2013). Analiza sezonalnosti turizma u Hrvatskoj primjenom metode Gini koeficijenta. Ekonomski pregled. 64 (2), 159-182.

Krakover, S. (2000). Partitioning seasonal employment in the hospitality industry. Tourism Management. 21, 461-471.

Mourdoukoutas, P. G. (1988). Seasonal Employment and Tourist Development: The Case of the Greek Islands (pp. 1-174). University Microfilms.

Obadić, A., Marić, I. (2009). The Significance of Tourism as an Employment Generator of Female Labour Force. Ekonomska misao i praksa/Economic Thought and Practice. Br. 1, ISSN: 1330-1039, UDK/UDC: 769.5 (331.526), 93-114, University of Dubrovnik.

OECD Database (2016). Retrieved November 19, 2016 from https://data.oecd.org/greece.htm

OECD Database (2016). Retrieved November 19, 2016 from https://data.oecd.org/italy.htm

OECD Database (2016). Retrieved November 19, 2016 from https://data.oecd.org/spain.htm

Oxford Economics (2016). WTTC/Oxford Economics 2016 Travel \& Tourism Economic Impact Research Methodology, March 2016, Oxford, UK.

Parrett, L. (2004). Women in Tourism Employment - A Guided Tour of the Greenwich Experience. Research Report, London Thames Gateway Forum.

Rašić Bakarić, I. (2016). Turizam. Sektorske analize, 49 (5), 1-24. ISSN: 1848-8986, Ekonomski institut Zagreb.

Smeral, E. (2016). Measuring the economic impact of tourism: the case of Lower and Upper Austria. Tourism Review, 70(4), 289-297.

UNESCO (2012). International Standard Classification of Education ISCED 2011. UNESCO Institute for Statistics, Montreal, Quebec, Canada.

UNWTO (2016). Tourism Highlights 2016 Edition. World Tourism Organization, Madrid, Spain Retrieved November 21, 2016 from available at: http://www.e-unwto.org/doi/ pdf/10.18111/9789284418145

WTTC (2016). WTTC Data Gateway. World Travel and Tourism Council. Retrieved November 22, 2016 from http://www.wttc.org/datagateway/

Yeşiltaş, M., Őztürk, Y., Hemmington, N. (2010). Tourism Education in Turkey and Implications for Human Resources. Anatolia: An International Journal of Tourism and Hospitality Research, 21(1), 55-71. 


\section{NOTES}

1 The number of nights spent (by residents and non-residents) can be put into perspective by making a comparison with the size of each country in population terms, providing an indicator of tourism intensity (Eurostat, 2015).

${ }^{2}$ Direct contribution to GDP indicates industries that deal directly with tourists, including hotels, travel agents, airlines and other passenger transport services, as well as the activities of restaurants and leisure industries that deal directly with tourists (World Travel and Tourism Council, 2016).

3 There are three major groups of educational level: less than primary, primary and lower secondary education (levels 0-2), upper secondary and post-secondary non-tertiary education (levels 3 and 4) and tertiary education level (levels 5-8), (UNESCO, 2012). 